DOI https://doi.org/10.30525/978-9934-26-006-3-24

\title{
АНТИБАКТЕРІАЛЬНА АКТИВНІСТЬ ПРЯМИХ ЕМУЛЬСІЙНИХ СИСТЕМ КАПРИЛОВО-КАПРИКОВОГО ТРИГЛЦЕРИДУ, СТАБІЛІЗОВАНИХ СУМІШШЮ СЕКОІЗОЛАРИЦИРЕЗИНОЛ ДИГЛІКОЗИДУ ТА ІЗЕТІОНАТКОКӦ̈ЛОМ НАТРІЮ
}

\begin{abstract}
Галиця I. B.
старший лаборант кафедри професійно-практичного ичику дисииплін лабораторного профілю

К3 «Запорізький медичний фаховий коледж» Запорізької обласної ради м. Запоріжжя, Украӥна
\end{abstract}

Галиця В. В.

доктор хімічних наук, викладач-методист кафедри професійно-практичного ичклу дисииплін лабораторного профілю К3 «Запорізький медичний фаховий коледж» Запорізької обласної ради, провідний фахівець ПНВП «Запоріжхімзбут» м. Запоріжжя, Украӥна

Яковійчук О. В.

старший викладач кафедри неорганічної хімії та хімічної освіти Мелітопольський державний педагогічний університет імені Богдана Хмельницького м. Мелітополь, Запорізька область, Украӥна

Різноманіття емульсій зумовлене їх специфічними властивостями, а саме поєднанням полярної та неполярної фаз, можливістю додавання різних біологічно активних компонентів, але найбільш затребуваними $\epsilon$ емульсії, які активно застосовуються в медичній практиці та яким притаманні антибактеріальні, фунгіцидні, ранозагоювальні, дезінфікуючі властивості за рахунок ефекту зволоження шкіри та глибокого проникнення до неї неполярної фази. Особливої уваги заслуговують прямі концентровані емульсії, стабілізовані ПАР природного походження [1, с. 105; 4, с. 17-24]. Нами було одержано прямі емульсійні системи каприлово-каприкового тригліцериду, стабілізованого сумішшю секоізоларицирезинол диглікозиду (нПАР) та ізетіонаткокоїлом натрію (аПАР) у співвідношенні $0,15: 1$ (1 : 7). У якості структуроутворювача використовували мірициловий спирт 
(гентріаконтанол-1) до 4,7\% за масою. При такому співвідношенні компонентів одержано агрегативно стійкі емульсійні системи [1, с. $105 ; 2$, с. 7-8]. Секоізоларицирезинол диглікозид (2,3-біс(3метокси-4-гідроксифенілен)бутан-1,4-діол диглікозид) було одержано 3 насіння льону олійного (Linum usitatissimum) за методикою, розробленою у Centre de Valorisation des Glucides et Produits Naturels (м. Дюри, Франція) - ПАР, яка не дисоціює в розчинах, виключно природного походження 3 вираженою біологічною активністю [6, c. 26-29; 7, c. 21-23; 9, p. 1147-1157; 10, p. 299-311].

Метою нашої роботи було дослідження антибактеріальних властивостей прямих концентрованих емульсій каприлово-каприкового тригліцериду, які містять у якості нПАР секоізоларицирезинол диглікозид із заміною у них водної фази гідрозолями наночастинок алюмінію, цинку, аргентуму, бісмуту та мангану. Гідрозолі було одержано класичними методами: алюмінію, цинку та мангану осадженням розчином амоніаку 3 подальшим диспергіюванням та пептизацією, аргентуму - реакцією срібного дзеркала (з використанням водного розчину $D, L$-глюкози зі співвідношенням масових концентрацій $2: 1$ ), бісмуту - методом гідролізу. Одержані гідрозолі наночастинок були агрегативно та кінетично стійкими протягом тривалого часу (до 8-9 місяців) та зберігали свої індивідуальні властивості (розмір частинок, концентрацію дисперсної фази, інтервал дзета-потенціалу від 36 до $49 \mathrm{mB}$ та інтервал $\mathrm{pH}$ агрегативної стійкості 6,9-8,7 од.). Окремо до неполярної фази було введено структуроутворювач 3 подальшим нагріванням до $85^{\circ} \mathrm{C}$, що сприяло гомогенізації фаз. У результаті охолодження до $25^{\circ} \mathrm{C}$ утворювалася пряма концентрована емульсія. Нашими експериментальними дослідженнями доведено, що співвідношення концентрацій нПАР (секоізоларицирезинол диглікозид) до аПАР (ізетіонаткокоїл натрію) $\epsilon$ $0,15: 1$, а це, в свою чергу, дає можливість стабілізації більш ніж 8,5\% неполярної фази емульсії. При цьому була проведена заміна водної фази вищенаведеними гідрозолями наночастинок.

Антибактеріальну активність було досліджено на таких мікроорганізмах: St. aureus, E. coli, Ps. aeruginosa, Cl. perfringens та B. subtilis. Культури висіювалися на поживні середовища МПБ, зокрема Cl. perfringens, яка висіювалася на середовищі Вільсона-Блера у стерилізовані чашки Петрі. Надалі диски фільтрувального паперу окремо просочувалися гідрозолями наночастинок та емульсіями, які замість водної фази містили вищенаведені гідрозолі. Для кожної культури дослідження проводили у п'ятикратній повторюваності $(\mathrm{p}<0,05)$. Усі культури знаходилися у термостаті при температурі $30^{\circ} \mathrm{C}$ протягом двох діб. Оцінка антибактеріальної активності полягала у вимірюванні ареола навколо нанесеної плями, при цьому його 
збільшення вказувало на ефективність пригнічення емульсією того чи іншого мікроорганізму. Найменша ефективність спостерігалася при пригніченні росту $E$. coli та $C l$. perfringens, хоча у випадку гідрозолів мангану та бісмуту ефект збільшувався, що свідчить про пошкодженні генетичного апарату мікроорганізму. Значне пригнічення росту B. subtilis спостерігалося у випадку застосування гідрозолів бісмуту, аргентуму та цинку, найменша - при заміні водної фази на гідрозоль наночастинок алюмінію.

У випадку Ps. aeruginosa найбільш ефективними емульсійними системами були ті, що містили наночастинки аргентуму та цинку, а найменш - мангану та алюмінію.

При цьому слід зауважити, що активність наведених емульсійних систем залежить виключно від природи наночастинок. Гідрозолі аргентуму, цинку та бісмуту власне проявляють бактеріостатичну та бактерицидну активність (у залежності від їх концентраціі), а заміщення ними водної фази при комбінації із секоізоларицирезинол диглікозидом посилює вищезазначений ефект.

Також слід звернути увагу на те, що одержані гідрозолі наночастинок мають майже нейтральне або слабколужне значення агрегативної стійкості, що не впливає на стійкість емульсій.

\section{Література:}

1. Галиця В.В. Вплив процесів асоціації мелісилового спирту (тріаконтанолу-1) на реологічні властивості емульсійних систем каприлово-каприкового тригліцериду. Хімічні проблеми сьогодення (XПС-2020): Збірник тез доповідей III Міжнародн. (XIII Української) наук. конф. (Вінниця, 25-27 березня 2020 р.). Вінниця: ДНУ ім. Василя Стуса, 2020. С. 105.

2. Галиця В.В. Одержання, колоїдно-хімічні та біологічні властивості концентрованих емульсійних систем, стабілізованих сумішами ПАР: автореф. дис... докт. наук: 02.00.11. Київ, 2016. 32 с.

3. Деркач С.Р., Левачев С.М., Кукушкина А.Н. Вязкоупругость концентрированных эмульсий, стабилизированных бычьим сывороточным альбумином в присутствии неионного ПАВ. Коллоидный журнал. 2007. Т. 69, № 2. С. 170-177.

4. Королева М.Ю., Юртов Е.В. Наноэмульсии: свойства, методы получения и перспективные области применения. Успехи химии. 2012. T. 81. C. 17-24.

5. Кутц Г. Косметические кремы и эмульсии: состав, получение, методы испытаний. М. Косметика и медицина, 2004. 235 с.

6. Стасевич, О.В., Михаленок С.Г., Курченко В.П. Эффективный способ получения лигнансодержащего экстракта из семян льна масличного. Вестн. БГУ. 2009. № 2. С. 26-29.

106 
7. Стасевич, О.В., Михаленок С.Г., Курченко В.П. Выделение секоизоларицирезинола диглюкозида из лигнансодержащего экстракта Linum usitassimum. Химия природных соединений. 2009. № 1. С. 21-23.

8. Hu C., Yuan Y.V., Kitts D.D. Antioxidant activities of the flaxseed lignan secoisolariciresinol diglucoside, its aglycone secoisolariciresinol and the mammalian lignans enterodiol and enterolactone in vitro. Food and Chemical Toxicology. 2007. Vol. 45. P. 2219-2227.

9. Muir A.D. Flax lignans - analytical methods and how they influence our understanding of biological activity. Journal of AOAC International. 2006. Vol. 89, № 4. - P. 1147-1157.

10. Schimdt T.J. A combined HPLC-UV and HPLC-MS method for the identification of lignans and its application to the lignans of Linun usitatissimum L. and L. bienne Mill. Phytochem-Analysis. 2006. Vol. 17. P. 299-311.

DOI https://doi.org/10.30525/978-9934-26-006-3-25

\section{ЕКСПЕРИМЕНТАЛЬНЕ ДОСЛІДЖЕННЯ АНТИОКСИДАНТНОЇ АКТИВНОСТІ ДІЕТИЧНОЇ ДОБАВКИ «ХЛОРОФІЛ» ЗА ІНГІБІЮВАННЯМ NO-РАДИКАЛУ}

\section{Горбунова А. П.}

спеціаліст вищої кваліфікаційної категорії, викладач-методист, завідувачка кафедри природничо-наукових дисциплін КЗ «Запорізький медичний фаховий коледж» Запорізької обласної ради

Толмосова Н. М.

спеціаліст вищої кваліфікаційної категорії, викладач-методист, завідувачка кафедри професійно-практичного ичику дисциплін лабораторного профілю

КЗ «Запорізький медичний фаховий коледж» Запорізької обласної ради

Лук'яненко О. Ю.

спеціаліст вищої категорії,

завідувачка науково-методичної лабораторії, старший викладач КЗ «Запорізький медичний фаховий коледж» Запорізької обласної ради м. Запоріжжя, Україна

На сьогодні проблема дослідження антиоксидантної активності у потенційних біологічно активних речовин не втрачає своєї актуальності та 